find its service increase in importance as he makes his way into the highest parts of the subject.

Of course no attempt is here made to attack D-ism, but to state that it and Dot-ism have their proper spheres, the Iatter generally, with more or less appropriateness, throughout the whole realm of functions, the former in the realm of motion, where the functions are functions of $t$-the sway over which realm was originally given to it by Newton, and acknowledged, as I have been told, by the D-ist Lagrange.

Glasgow College

Thomas MUir

\section{Occurrence of the Eagle Ray}

A DOUBLE-SPINED specimen of the eagle ray (Myliobatis aquila), taken in Torbay on the Ist Nov., has been presented to this museum by Mr. Frank Gosden, fish dealer, High Street, Exeter. Its dimensions are as follows:--Breadth across the fins, $2 \mathrm{ft}$. 3 l. in. ; length from snout to the base of the spines, Ift. 7 in. ; total length from snout to extremity of the tail, 3ft. 61: in.

W. S. M. D'URBAN, Curator

Albert Memorial Museum, Exeter

\section{Deep Sea Dredging}

WHILE winter allows of time for complete arrangements to be made in anticipation of dredging weather, will you permit me to raise the question of the conditions under which our knowledge of the natural history of the sea may be most readily extendedl?

As a rule, yacht owners object to the fatigue and dirt of dredging, but as we have the successful example of the Norna, may we not hope that other yachts may further the cause of science, if assistancel in the way of instruction or apparatus be afforded to them by those having the necessary experience and means?

The idea of now urging the question is not mine alone, but is entertained by many ardent naturalists who are much in favour of a skilful search of our seas at home, as well as of the Mediterranean and other distant and almost untried seas.

Your pages have often borne witness to the interest and importance attaching to marine zoology, and if men of practical experience, such as Carpenter, W. Thomson, Marshall Hall, \&c., will indicate the best localities for search and the best measures to adopt, we may hope that others may follow in their steps, and that the large aquaria now built and building. will be sup. plied, as only private zeal and enterprise can compass, with new and rare specimens from deep waters.

Milton House, Clarence Street, Brighton, Dec. 5

T. H. Hennah

\section{The Solar Halo}

THE solar halo of the morning of the 13 th ult. described in your last number as seen near, and at about thirty miles from, Durham, and which Prof. A. S. Kerschel conjectures may have been seen from more distant stations, was visible here.

I first saw it at about $8 \mathrm{~A} . \mathrm{M}$., when it appeared as the arc of a circle, with a very short portion of an inverted arc touching it at circle, with - the sun itself being hidden by a bank of cloud, from behind which issued several radiating spikes. Shortly after halfpast nine this halo had disappeared, except a small portion at the point of contact of the two arcs, vertically over the sun, which appeared like a bright elongated patch, forked at each end, and projected not on mist, but on blue sky, and tinged witl clull prismatic colours, which were most strongly marked in the inverted arc, in which the red or orange was downwards, or on the outside of the circle. I then suddenly caught sight of a second halo, of much greater radius than the first--visible through perhaps $130^{\circ}$ or $140^{\circ}$ of arc, above, and to the right of, the sun, projected on the clear blue sky, but so faintly that it might easily have been missed. This outer circle exhibited the prismatic colours with a purity and delicacy that I have never before seen in halos, and which was quite different to the ordinary dull, muddy colours. In fact, it had just the appearance of a very muddy colours. outside the circle. I was shortly after able to borrow a sextant, and measured the distance from the sun to the bright patch and the outer circle, which appeared respectively $21^{\circ} 40^{\prime}$ and $43^{\circ} 20^{\prime}$; but they were already growing so faint that I was runable to do this with much precision. Except the bright patch before do this with much precision. named, I did not observe any appearance Ge. C. THOMPSON
Cardiff, Dec. 4
GEO.

\section{ON THE ZIPHIOID WHALES}

THE peculiar division of Cetaceans to which the term "Ziphioid" is now commonly applied, from one of the earliest known forms, Ziphizs of Cuvier," is in many respects one of the most interesting of the order. They form a very compact group, united closely together by the common possession of very definite structural characters, and as distinctly separated from all other groups by equally definite characters.

With the singular exception of Hyperoodon rostratus (the structure and habits of which species are as well known, perhaps, as those of any other cetacean), no specimen of the group had ever come under the notice of any naturalist up to the commencement of the present century. Since that time, however, at irregular intervals, in various and most distant parts of the world, solitary individuals have been caught or stranded, now amounting to nearly thirty, these being by some naturalists referred to upwards of a dozen distinct species and to very nearly as many genera. No case is recorded of more than one of these animals having been observed at one place at a time, and their habits are almost absolutely unknown. Their very presence in the ocean seems to pass unnoticed and unsuspected by voyagers, and even by those whose special occupation is the pursuit and capture of various better known and more abundant cetaceans, until one of the accidental occurrences just alluded to reveals the existence of forms of animal life of considerabie magnitude, and at least sufficiently numerous to maintain the continuity of the race.

This comparative rarity at the present epoch contrasts greatly with what at one time obtained on the earth, especially in the period of the crag formations, and leads to the belief that the existing ziphioids are the survivors of an ancient family which once played a far more important part than now among the cetacean inhabitants of the ocean, but which have been gradually replaced by other forms, and are themselves probably destined ere long to share the fate of their once numerous allies or progenitors.

The Ziphioid whales belong to the great primary division or sub-order of the Odontocetes or Toothed whales, as distinguished from the Whalebone whales. They are allied on the one hand to the Cachalots or Sperm whales, and on the other to the true Dolphins and Porpoises, but more nearly to the former than the latter. They are animals varying between fifteen and thirty feet in length, and in external characters very closely resemble each other, all having small pointed snouts or "beaks," small rounded or oval pectoral fins or "flippers," a comparatively small triangular dorsal fin, situated considerably behind the middle of the back, and a single "blowhole" of concentric form, situated in the middle of the top of the head One of their most obvious characteristics, distinguishing them from the true dolphin, is the complete absence of teeth (except occasionally a few mere rudiments concealed in the gum) in the upper jaw, while in the lower jaw there is usually but a single pair, which in some species may be greatly developed and project like tusks from the mouth, though sometimes even these are rudimentary and covered up by the gum, so that the animal is practically toothless. In addition to these external and easily-recognised characters, there are others connected with the skeleton and internal organs which separate them still more trenchantly from the other members of the order. Their food appears

* "J'appliquerai au genre dont elle (a skull found on the shore of the Mediterranean) devient le premier type, le nom de Ziphius, employé par quelques auteurs du moyen age (Voyez Gesner I., p., 20g) pour un cétacé qu'ils n ont point déterminé" (Cuvier," "Ossemens fossiles"). Accordıng to strict rules of prority "Hyperodontoid" would be the more correct term, as Hyperoodon was the first genis of the group distinctly characterised; but as the name is erroneous in its signification, it will be better to keep to the more generally adopted and less objectionable term of "Ziphioid" hets" 